\title{
Pengembangan Instrumen Telaah RPP Dan Supervisi Akademik Berbasis Keterampilan Abad 21 Guru Sekolah Binaan SPMI Kota Palangka Raya
}

\author{
I Wayan Sarman \\ Pengawas Madya Dinas Pendidikan Provinsi Kalimantan \\ Tengah, Indonesia \\ Email: sarmanwayan@yahoo.com
}

Diterima: 01 Mei 2020; Disetujui: 06 Mei 2020; Diterbitkan: 08 Mei 2020

\begin{abstract}
ABSTRAK
Menyusun RPP mengacu pada karakteristik peserta didik belum sesuai dengan tuntutan pembelajaran abad 21. Jalan pintas yang dilakukan guru adalah menggunakan RPP sekolah lain. Akibatnya indikator pencapaian kompetensi (IPK), model pembelajaran, dan penilaian tidak sesuai KD. Penelitian ini bertujuan mengembangkan instrumen telaah RPP dan supervisi pembelajaran berbasis keterampilan abad 21 menggunakan research and development ( $\mathrm{R} \& \mathrm{D})$. Desain model pengembangan instrumen ada tiga, yaitu: 1) studi pendahuluan melalui review instrumen telaah RPP dan supervisi pembelajaran, 2) tahap pengembangan yaitu telaah kesesuaian instrumen, validasi telaah instrumen menurut ahli, menyusun instrumen berdasarkan hasil validasi, dan 3) tahap evaluasi uji kepraktisan instrumen telaah RPP dan supervisi pembelajaran. Hasil penelitian menunjukkan bahwa (1) model faktual instrumen telaah RPP dan supervisi pembelajaran di Provinsi Kalimantan Tengah belum memenuhi kesesuaian kegiatan pendahuluan, inti, dan penutup maupun deskripsi dalam RPP, sehingga belum digunakan sebagai acuan guru dalam menyempurnakan RPP; (2) pengembangan instrumen diawali dengan, (a) melakukan kajian literatur sehingga diperoleh 5 (lima) komponen RPP dan tiga tahapan pelaksanaan supervisi, (b) melakukan validasi instrumen menurut ahli meliputi sahih (akurasi), tingkat kepentingan, dan kebermanfaatan dengan rata-rata prosentase mencapai 92,19. Tahap evaluasi yaitu melakukan uji coba kepraktisan instrumen menunjukkan (a) observer menjadi mudah melakukan telaah RPP dan supervisi pembelajaran, (b) membantu guru dalam menyempurnakan RPP sesuai dengan substansi minimal dalam RPP, (c) sekolah memiliki alat ukur telaah RPP dan supervisi pembelajaran, dan (d) Instrumen berbasis excel yang berhasil dikembangkan mengacu keterampilan guru abad 21 dan revolusi industri 4.0.
\end{abstract}

Kata Kunci: abad 21, instrumen telaah RPP, SPMI, supervisi

\section{PENDAHULUAN}

Indikator sekolah bermutu yaitu peserta didik cerdas spiritual, emosional dan sosial, intelektual, dan kinestetis melalui pemenuhan standar nasional pendidikan (SNP). Pemenuhan 8 SNP menurut BSNP (2019) ditandai dengan pencapaian out put pendidikan yaitu standar kompetensi lulusan (SKL) memenuhi 
kompetensi pada dimensi sikap, pengetahuan, dan keterampilan. Pada tahapan ini kreativitas, dan inovasi kepala sekolah, guru, tenaga kependidikan, dan pengawas sekolah ditantang untuk mampu mengoptimalkan input (standar pendidik dan tenaga kependidikan, standar sarana dan prasana, serta standar pembiayaan), dan proses (standar isi, standar proses, standar penilaian), dan standar pengelolaan menghasilkan tiga kriteria sekolah yaitu kategori belum menuhi SNP, memenuhi SNP, dan melampaui SNP.

Mutu satuan pendidikan tercermin melalui rapor pemetaan mutu pendidikan (PMP) yang telah dicapai sekolah. Hasil rapor mutu SMP, SMA, dan SMK Provinsi Kalimantan Tengah tahun 2019 menunjukkan bahwa belum ada sekolah yang mencapai SNP. Level tertinggi pencapaian sekolah jenjang SMP berada pada kategori menuju SNP 4 ada 507 sekolah dari 715 (70,91\%), jenjang SMA ada 159 dari 199 sekolah $(79,89 \%)$ jenjang SMK yaitu 75 sekolah dari 112 SMK (66,96\%). Jika dibandingkan dengan hasil rapor mutu SMP, SMA, dan SMK SPMI wilayah Kota Palangka Raya, yaitu fokus pada sekolah binaan peneliti di SMA Negeri 4 Palangka Raya, SMA Nusantara, SMK Karsa Mulya, dan SMP Muhammadiyah Palangka Raya menunjukkan bahwa akar permasalahan adalah masih rendahnya SKL yaitu pada dimensi pengetahuan. Hal ini disebabkan rendahnya capaian sub indikator peserta didik pada pengetahuan faktual, prosedural, konseptual, dan metakognitif.

Rendahnya capaian SKL peserta didik berdampak belum tercapainya SNP pada sekolah binaan SPMI Kota Palangka Raya. Faktor penyebabnya berasal dari: (1) standar isi yaitu sekolah belum menyusun perangkat pembelajaran sesuai rumusan kompetensi lulusan, (2) standar proses yaitu rencana pelaksanaan pembelajaran (RPP) belum mendapatkan evaluasi dari kepala sekolah dan pengawas sekolah, (3) standar penilaian yaitu pemahaman pendidik terhadap proses penilaian masih belum maksimal, (4) standar PTK yaitu kepala sekolah belum berkompetensi supervisi minimal baik, (5) standar sarana dan prasarana yaitu sekolah belum memiliki sarana dan prasarana pembelajaran yang lengkap dan layak, (6) standar pengelolaan yaitu kepala sekolah belum berkinerja baik dalam melaksanakan tugas kepemimpinan, dan (7) standar pembiayaan yaitu sekolah belum mengatur alokasi dana yang berasal dari APBD/APBN/Yayasan/sumber lainnya secara akuntabel.

Rekomendasi prioritas yang dirumuskan pada sekolah binaan SPMI Kota Palangka Raya untuk satu tahun ke depan yaitu (1) perlu peningkatan kompetensi guru dalam penyusunan perangkat pembelajaran terkait kompetensi sikap dan keterampilan, (2) perlu menyusun perangkat pembelajaran dengan mengintegrasikan penilaian sikap dalam pembelajaran menggunakan lembar observasi dan jurnal, (3) perlu peningkatan pemahaman mengembangkan perangkat instrumen penilaian sikap, pengetahuan, dan keterampilan dalam proses pembelajaran, (4) perlu meningkatkan komitmen kepala sekolah menjalankan tugas supervisi dan evaluasi secara berkala dan berkelanjutan, serta (5) perlu mengupayakan kepala sekolah berkinerja baik dalam melaksanakan tugas kepemimpinan.

Berdasarkan 5 (lima) rekomendasi di atas maka pemenuhan mutu sekolah dapat dilakukan dengan melaksanakan supervisi akademik yang diawali dengan melakukan telaah RPP. Menurut DiPaola \& Hoy (2014) supervisi adalah proses untuk membantu guru menjadi lebih efektif dalam membantu siswa dengan 
serangkaian kegiatan yang dirancang untuk meningkatkan proses belajar mengajar. Artinya pengawas sekolah harus mampu memberikan bantuan profesional kepada guru agar mampu menyusun RPP sesuai regulasi, mudah dipahami, dan praktis, serta pelaksanaan supervisi mengacu pada RPP yang telah disempurnakan.

Tujuan supervisi akademik menurut Kemendikbud (2018) menyimpulkan bahwa proses pembelajaran adalah untuk mengetahui: (1) kompetensi guru dalam membuat persiapan atau perencanaan pembelajaran; (2) ketepatan dalam memilih pendekatan, model, metode, dan teknik pembelajaran; (3) kompetensi guru sebagai tenaga profesional dalam melaksanakan proses pembelajaran; (4) kompetensi guru dalam mengembangkan instrumen penilaian; (5) melaksanakan evaluasi, baik evaluasi selama proses pembelajaran atau evaluasi hasil belajar; (6) kemampuan guru dalam memberikan tindak lanjut pembelajaran kepada siswa; dan (7) kelengkapan administrasi pembelajaran. Oleh sebab itu, tahapan supervisi akademik diawali dengan melakukan telaah RPP sesuai dengan regulasi kekinian yaitu Permendikbud Nomor 34 Tahun 2018 tentang Standar Proses SMK.

Uraian di atas menunjukkan bahwa poin 1, 2, 4, dan 7 adalah terkait dengan proses menyusun RPP sedangkan poin 3, 5 dan 6 mengacu pada pelaksanaan supervisi akademik. Penting memberikan bimbingan professional kepada guru-guru khususnya melakukan telaah RPP dan supervisi pembelajaran secara optimal. Namun instrumen RPP dan supervisi mengacu pada integrasi keterampilan abad 21 belum dilakukan pengembangan instrumen yang tepat dan terukur untuk memperoleh data proses pembelajaran. Sugiyono (2013) menyebutkan bahwa instrumen merupakan alat ukur yang dugunakan untuk mendapatkan informasi kuantitatif tentang variasi karakteristik variabel secara objektif. Artinya sebelum melakukan supervisi pembelajaran maka harus diawali dengan melakukan telaah RPP menggunakan instrumen yang terukur. Oleh sebab itu, maka penulis melakukan penelitian dengan judul: "Pengembangan instrumen telaah RPP dan supervisi akademik berbasis keterampilan abad 21 guru sekolah binaan SPMI Kota Palangka Raya”.

\section{METODE PENELITIAN}

Rancangan penelitian ini adalah Research and Development ( $\mathrm{R} \& \mathrm{D})$. Winarni, E.W, (2018: 248) menyimpulkan penelitian pengembangan instrumen telaah RPP dan supervisi pembelajaran yaitu proses untuk mengembangkan produk baru atau menyempurnakan produk yang telah ada sehingga dapat dipertanggungjawabkan. Sugiyono (2013:407) menyatakan metode penelitian pengembangan adalah metode yang digunakan untuk menghasilkan produk tertentu, dan menguji keefektifan produk tersebut. Dengan demikian penelitian pengembangan instrumen telaah RPP dan supervisi pembelajaran adalah proses menyempurnakan instrumen melalui tahapan-tahapan yang telah ditentukan.

Desain model pengembangan yang digunakan adalah desain $\mathrm{R} \& \mathrm{D}$. Sugiyono (2013:434) mengelompokkan menjadi tiga tahap, yaitu: 1) tahap studi pendahuluan, 2) tahap studi pengembangan, dan 3) tahap evaluasi. Penelitian ini terdiri dari tiga tahap yaitu (1) studi pendahuluan dengan melakukan review instrumen telaah RPP dan supervisi pembelajaran, (2) tahap pengembangan melalui telaah kesesuaian instrumen, validasi telaah instrumen menurut ahli, 
menyusun instrumen berdasarkan hasil validasi dan (3) tahap evaluasi uji kepraktisan instrumen supervisi pembelajaran.

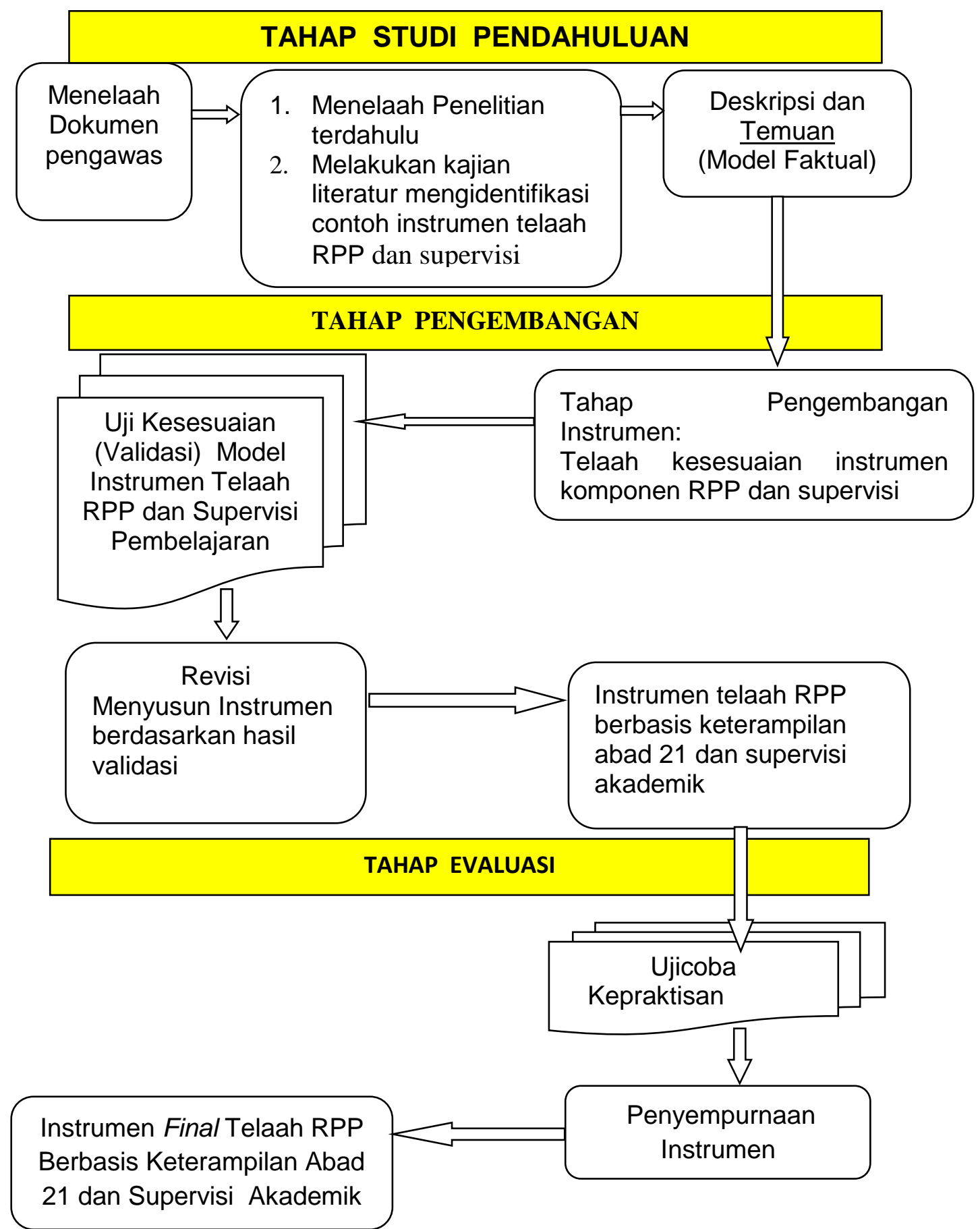

Gambar 1 Tahapan Penelitian Pengebangan Instrumen Telaah RPP Supervisi Akademik Berbasis keterampilan Abad 21 (Sugiyono, 2013: 434)

Subjek penelitian ini adalah kepala sekolah dan guru-guru pada sekolah binaan SPMI Kota Palangka Raya Semester 2 Tahun Pelajaran 2018/2019 sebanyak 16 orang (4 kepala sekolah dan 12 guru-guru sebagai TPMPS). Guru sasarannya adalah 32 orang melalui telaah RPP sekaligus supervisi pembelajaran. 
Penelitian dilakukan di sekolah binaan SPMI Kota Palangka Raya yakni SMA Negeri 4 Palangka Raya, SMA Nusantara, SMK Karsa Mulia, dan SMP Muhammadiyah Palangka Raya karena peneliti adalah fasda pemenuhan mutu pelaksanaan SPMI di sekolah tersebut.

Pengembangan instrumen telaah RPP dan supervisi pembelajaran menggunakan tiga tahap, yaitu: 1) Tahap Studi Pendahuluan, 2) Tahap Pengembangan, dan 3) Tahap Evaluasi. Secara rinci ditunjukkan pada Gambar 1.

\section{HASIL PENELITIAN DAN PEMBAHASAN}

Pengolahan hasil dan pembahasan pada penelitian ini terdiri dari 3 aspek yaitu (1) Tahap Pendahuluan melalui Review Instrumen Telaah RPP dan Supervisi (2) Tahap Pengembangan Instrumen Telaah RPP dan Supervisi Pembelajaran, dan (3) Tahap Evaluasi dengan Uji Coba Kepraktisan Instrumen.

\section{Tahap Pendahuluan melalui Review Instrumen Telaah RPP dan Supervisi}

Penelitian ini diawali dengan studi pendahuluan untuk mengungkapkan model faktual instrumen supervisi pengawas sekolah di Kota Palangka Raya Provinsi Kalimantan Tengah. Pada tahap ini penulis menelaah dokumen pengawas sekolah dan hasil penelitian terdahulu. Dokumen pengawas yang di telaah terkait dengan supervisi akademik (1) program tahunan, (2) program semester, dan (3) rencana pengawasan akademik. Penelitian terdahulu adalah milik Mulyadi (2018) yang telah melakukan penelitian tentang supervisi akademik di sekolah binaan.

Telaah program Rencana Pengawasan Akademik (RPA) pengawas memuat tentang aspek masalah dan tujuan. Permasalahan yang menjadi target penyelesaian yaitu memberikan pendampingan kepada guru-guru melakukan penyempurnaan RPP dan supervisi. Namun dalam RPA belum memuat instrumen telaah RPP dan supervisi pembelajaran.

Telaah pada hasil penelitian oleh Mulyadi (2018) tentang Pendekatan Supervisi Pengajaran Kolaboratif untuk Meningkatkan Kemampuan Guru Menyusun Rencana Pelaksanaan Pembelajaran Inovatif Bermuatan Nilai Karakter di SMK Binaan Kota Palangka Raya Semester 1 Tahun Pelajaran 2018/2019 juga belum mengembangkan semua aspek keterampilan abad 21. Nilai karakter yang dapat dimasukkan pada RPP adalah nilai karakter bangsa yang berorientasi pada tindakan dalam melaksanakan prosedur kerja. Artinya nilai karakter bangsa sesuai dengan Peraturan Pemerintah Nomor 87 Tahun 2017 tentang Penguatan Pendidikan Karakter (PPK) belum memuat kristalisasi karakter yaitu religiositas, nasionalisme, kemandirian, gotong royong, dan integritas.

Hasil kajian terhadap studi pendahuluan menunjukkan kondisi faktual supervisi akademik di Kota Palangka Raya diringkas pada Tabel 1.

Tabel 1 Kondisi Faktual Pelaksanaan Supervisi di Kota Palangka Raya Provinsi Kalimantan Tengah

\begin{tabular}{llll}
\hline No. & $\begin{array}{c}\text { Temuan Kondisi } \\
\text { Faktual }\end{array}$ & \multicolumn{1}{c}{ Kondisi Ideal } & \multicolumn{2}{c}{ Kelemahan } \\
\hline 1. & $\begin{array}{l}\text { Frekuensi supervisi } \\
\text { akademik pengawas }\end{array}$ & Frekuensi supervisi & Frekuensi supervisi \\
pembina $1-2 \mathrm{kali}$ & 6 kali dalam satu $/$ belum memenuhi \\
dalam satu semester & $\begin{array}{l}\text { semester / sesuai } \\
\text { kebutuhan guru }\end{array}$ & &
\end{tabular}




\begin{tabular}{llll}
\hline No. Temuan Kondisi & Kondisi Ideal
\end{tabular}
Faktual

2. Supervisi akademik Supervisi seharusnya Supervisi akademik dilaksanakan berdasarkan inisiatif pengawas sekolah inisiatif guru bukan keinginan pengawas bukan inisiatif guru pengawas

3. Layanan supervisi akademik hanya diberikan oleh pengawas atau kepala sekolah

4. Supervisi akademik dilaksanakan hanya berdasarkan jadwal yang telah ditentukan

Layanan akademik supervisi Layanan supervisi oleh dilakukan oleh guru kepala sekolah, dan guru yang tergabung dalamTPMPS, kepala sekolah, dan pengawas sekolah.

\section{Supervisi

$$
\text { akademik }
$$

dilaksanakan

berdasarkan kebutuhan guru/waktu tidak

dibatasi

5. Perencanaan lebih ditekan-kan pada pemisahan antara supervis administrasi dan observasi kelas

6. Potensi guru untuk saling membantu mengatasi masalah pada supervisi akademik belum dimanfaatkan secara terencana.

7. Tindak lanjut hasil supervisi akademik belum dilaksanakan dengan baik

Perencanaan supervisi diawali dengan melakukan telaah perangkat pembelajaran untuk dilanjutkan supervisi peleksanaan pembelajaran.

Guru senior dapat dimanfaatkan untuk membantu pelaksanaan supervisi akademik pengawas sekolah

Hasil-hasil temuan supervisi akademik ditindaklanjuti untuk menentukan kelompok guru memperoleh pembinaan langsung maupun tidak langsung

8. Pemantauan hasil tindak lanjut belum Tindak lanjut temuan hasil supervisi akademik dilaksanakan oleh tetap dipantau pengawas sekolah.

penyelesaiannya

9. Administrasi guruguru belum
Pengawas memberikan bimbingan profesional
Perencanaan supervisi

kunjungan kelas belum

diawali dengan

melakukan telaah

administrasi

pembelajaran

Potensi yang ada pada guru senior tidak berkembang dan cenderung bekerja sendiri-sendiri.

Guru cenderung mengabaikan temuantemuan hasil supervisi / mencari solusi sendiri.

Apabila tidak dipantau pelaksanaan temuan hasil supervisi maka ada kecenderungan guru temuan tersebut. Pengawas, kepala sekolah, dan guru-guru tuidak menindaklanjuti 


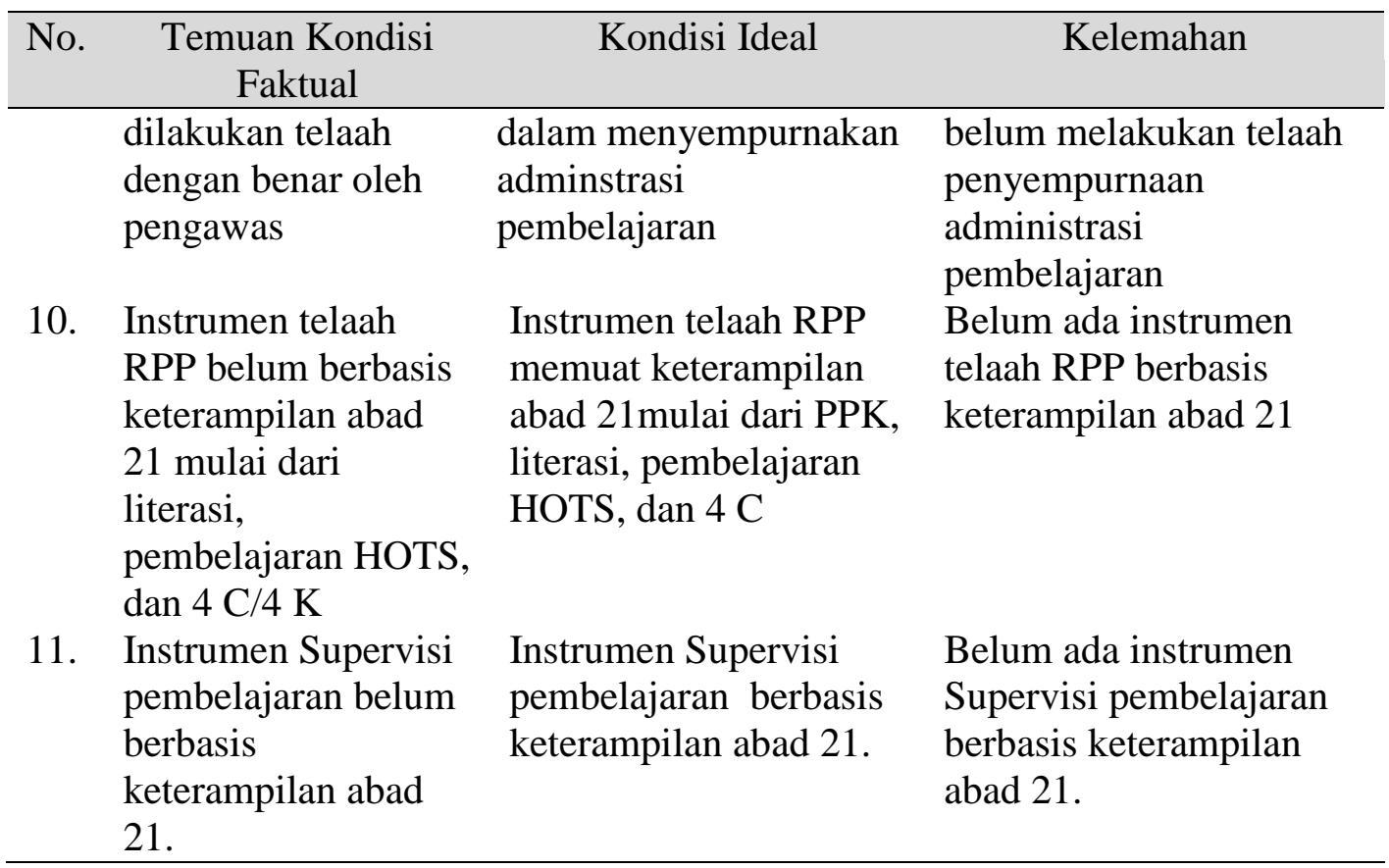

Tabel 1 menunjukkan pelaksanaan supervisi dimulai dari inisiatif pengawas dan bukan dari guru, frekuensinya minim, belum diawali dengan telaah RPP, dan belum ada instrumen telaah RPP berbasis keterampilan abad 21 . Berdasarkan kendala di atas, maka peneliti memberikan pendampingan kepada kepala sekolah, TPMPS, dan guru-guru untuk melakukan penyempurnaan RPP melalui telaah RPP berbasis keterampilan abad 21 pada keempat sekolah binaan SPMI (1) SMA Negeri 4 Palangka Raya, (2) SMA Nusantara Palangka Raya, (3) SMK Karsa Mulya Palangka Raya, dan (4) SMP Muhammadiyah Palangka Raya. Setelah memberikan paparan tentang tahapan penyempurnan RPP, maka guruguru melakukan penyempurnaan RPP. Tahap selanjutnya sesuai dengan kesepakatan antara kepala sekolah, TPMPS, dan sekolah membuatkan jadwal observer melaksanakan supervisi pembelajaran. Pada penelitian ini peneliti menunjuk observer untuk mendampingi guru-guru pada saat supervisi. Dengan memberikan kepercayaan kepada kepala sekolah dan TPMPS untuk melakukan tahapan supervisi di sekolah masing-masing.

\section{Tahap Pengembangan Instrumen Telaah RPP dan Supervisi Pembelajaran}

Kelengkapan komponen RPP secara subtansi yang harus ada yaitu (1) identitas mata pelajaran dan KD; (2) perumusan tujuan pembelajaran mengacu indikator pencapaian kompetensi; (3) proses pembelajaran memuat kegiatan pendahuluan, inti, dan penutup, dan (5) rancangan penilaian pembelajaran.

Komponen supervisi mengacu pada kesesuaian kegiatan pendahuluan, inti, dan penutup pada proses pembelajaran. Komponen tersebut meliputi (1) kegiatan pendahuluan terdiri atas orientasi, motivasi, dan apersepsi; (2) kegiatan inti terdiri dari pemilihan model pembelajaran, pemanfaatan sumber belajar/media pembelajaran, pengelolaan kelas dan pelibatan peserta didik, dan penggunaan bahasa yang benar dan tepat; (3) kegiatan penutup terdiri dari proses membuat rangkuman, refleksi, dan tindak lanjut, serta pelaksanaan penilaian hasil belajar. 
Instrumen telaaah RPP dan Supervisi pembelajaran yang telah disusun oleh peneliti dilanjutkan dengan menentukan kesesuaian instrumen menurut pendapat ahli yang memahami konsep supervisi pembelajaran. Validator 1 adalah Drs. Mulyadi, M.Pd (pengawas senior), validator 2 yaitu Prof. Dr. Suandi Sidauruk, M.Pd., validator 3, Dr. Gunarjo S. Budi, M.Sc., dan 4 Lukman Juhara, M.Pd (guru senior). Keempat validator telah melakukan validasi dengan tingkat kesesuaian instrumen pada Tabel 2

Berdasarkan hasil telaah kesesuaian instrumen menurut validator 1, 2, 3, dan 4 maka diperoleh validasi instrumen mencapai 92,19\%. Artinya instrumen sudah memenuhi kesesuaian dari aspek sahih, tingkat kepentingan, dan kebermanfaatan.

Tabel 2 menunjukkan hasil validator 4 memberikan deskripsi telaah sebagai berikut: "Setelah saya baca dan cermati beberapa kali, tampaknya Instrumen Telaah RPP dan Instrumen Supervisi Pembelajaran ini sangat mudah (praktis) untuk digunakan. Komponen RPP yang ditelaah dari sisi penguatan karakter dan keterampilan abad 21 juga telah terwakili”.

Tabel 2 Hasil Validasi Kesesuaian Instrumen Telaah RPP dan Supervisi Pembelajaran

\begin{tabular}{|c|c|c|c|c|c|c|}
\hline \multirow[b]{2}{*}{ No } & \multirow[b]{2}{*}{ Aspek } & \multirow[b]{2}{*}{ Indikator Penilaian } & \multicolumn{4}{|c|}{ Hasil Penilaian } \\
\hline & & & $\begin{array}{l}\text { Vali- } \\
\text { dator } \\
1 \\
\end{array}$ & $\begin{array}{l}\text { Vali- } \\
\text { dator } \\
2 \\
\end{array}$ & $\begin{array}{l}\text { Vali- } \\
\text { dator } \\
3 \\
\end{array}$ & $\begin{array}{l}\text { Vali- } \\
\text { dator } \\
4 \\
\end{array}$ \\
\hline \multirow{3}{*}{1} & \multirow{3}{*}{ Sahih } & $\begin{array}{l}\text { Sesuai dengan } \\
\text { Permendikbud }\end{array}$ & 2 & 2 & 2 & 2 \\
\hline & & Kesesuaian Komponen & 2 & 2 & 2 & 2 \\
\hline & & Bahasa & 2 & 2 & 2 & 2 \\
\hline \multirow{2}{*}{2} & \multirow{3}{*}{$\begin{array}{l}\text { Tingkat } \\
\text { Kepen- } \\
\text { tingan }\end{array}$} & $\begin{array}{l}\text { Kesesuaian dengan } \\
\text { karakteristik } \\
\text { pembelajaran abad } 21\end{array}$ & 2 & 2 & 2 & 2 \\
\hline & & $\begin{array}{l}\text { Kesesuaian dengan } \\
\text { kebutuhan guru }\end{array}$ & 2 & 1 & 1 & 2 \\
\hline \multirow{3}{*}{3} & & Kelengkapan komponen & 1 & 1 & 2 & 1 \\
\hline & \multirow{2}{*}{$\begin{array}{l}\text { Keber- } \\
\text { manfaata } \\
\mathrm{n}\end{array}$} & $\begin{array}{l}\text { Kebermanfaat instrumen } \\
\text { untuk pengembangan } \\
\text { RPP }\end{array}$ & 2 & 2 & 2 & 2 \\
\hline & & $\begin{array}{l}\text { Kebermanfaatan } \\
\text { instrumen untuk } \\
\text { supervisi pembelajaran }\end{array}$ & 2 & 2 & 2 & 2 \\
\hline & & Total & 15 & 14 & 15 & 15 \\
\hline & & Persentase & 93,75 & 87,5 & 93,75 & 93,75 \\
\hline & \multicolumn{2}{|c|}{ Persentase rata-rata } & \multicolumn{4}{|c|}{92,19} \\
\hline
\end{tabular}

Langkah selanjutnya adalah membuat aplikasi berbasis excel untuk instrumen telaah RPP dan supervisi pembelajaran. Tujuannya adalah 
memudahkan kepala sekolah dan pengawas untuk melakukan supervisi. File aplikasi berbasis excel ini dilengkapi dengan enam aspek. Pertama, paparan tentang integrasi keterampilan abad 21 mulai dari PPK, literasi, pembelajaran HOTS, dan 4 C. Kedua, taksonomi 1, cara membedakan pengetahuan faktual, konseptual, prosedural, dan metakognitif. Ketiga, taksonomi 2, memuat KKO digunakan untuk menurunkan IPK pengetahuan. Keempat, taksonomi 3, memuat KKO digunakan untuk menurunkan IPK keterampilan. Kelima, instrumen telaah RPP. Keenam, instrumen supervisi pembelajaran.

\section{Tahap Evaluasi dengan Uji Coba Kepraktisan Instrumen.}

Uji coba kepraktisan instrumen telaah RPP dan Supervisi pembelajaran telah dilakukan pada empat sekolah yaitu SMA Negeri 4 Palangka Raya, SMA Nusantara, SMK Karsa Mulya, dan SMP Muhammadiyah Palangka Raya. Dalam ujicoba instrumen ini peneliti telah melatih observer yang terdiri dari kepala sekolah dan guru yang tergabung dalam TPMPS yang pelaksanaannya sesuai jadwal yang ditetapkan di sekolah masing-masing. Hasil Perolehan Skor Uji Kepraktisan telaah RPP oleh observer seperti dinyatakan pada Gambar 2.

Gambar 2 menunjukkan bahwa instrumen telaah RPP dapat digunakan oleh observer. Mulai dari melakukan telaah kesesuaian komponen, deskripsi hasil pengamatan guru, dan integrasi keterampilan abad 21. Hasil uji kepraktisan instrumen supervisi seperti dinyatakan pada Gambar 3 menunjukkan instrumen supervisi pembelajaran pada empat sekolah dapat digunakan dan praktis untuk supervisi guru-guru.

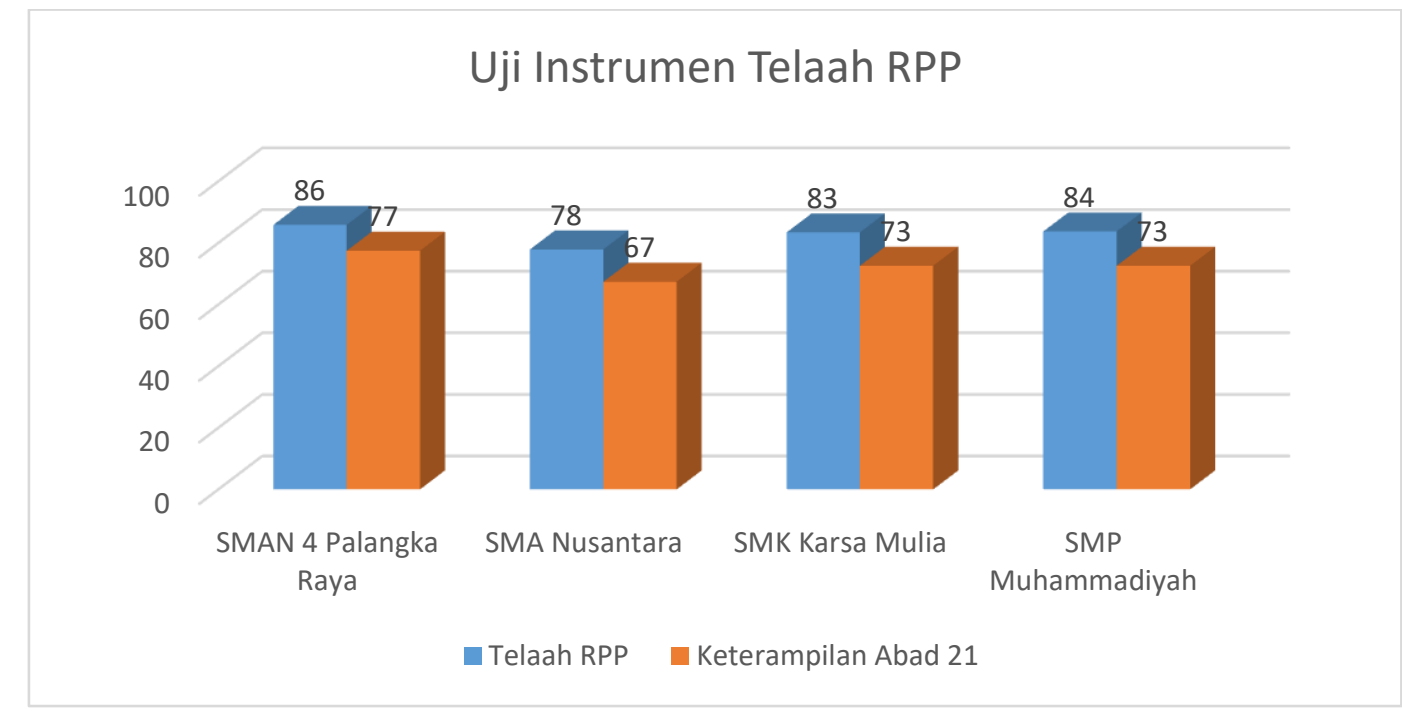

Gambar 2 Hasil Perolehan Skor Uji Kepraktisan Instrumen Telaah RPP 


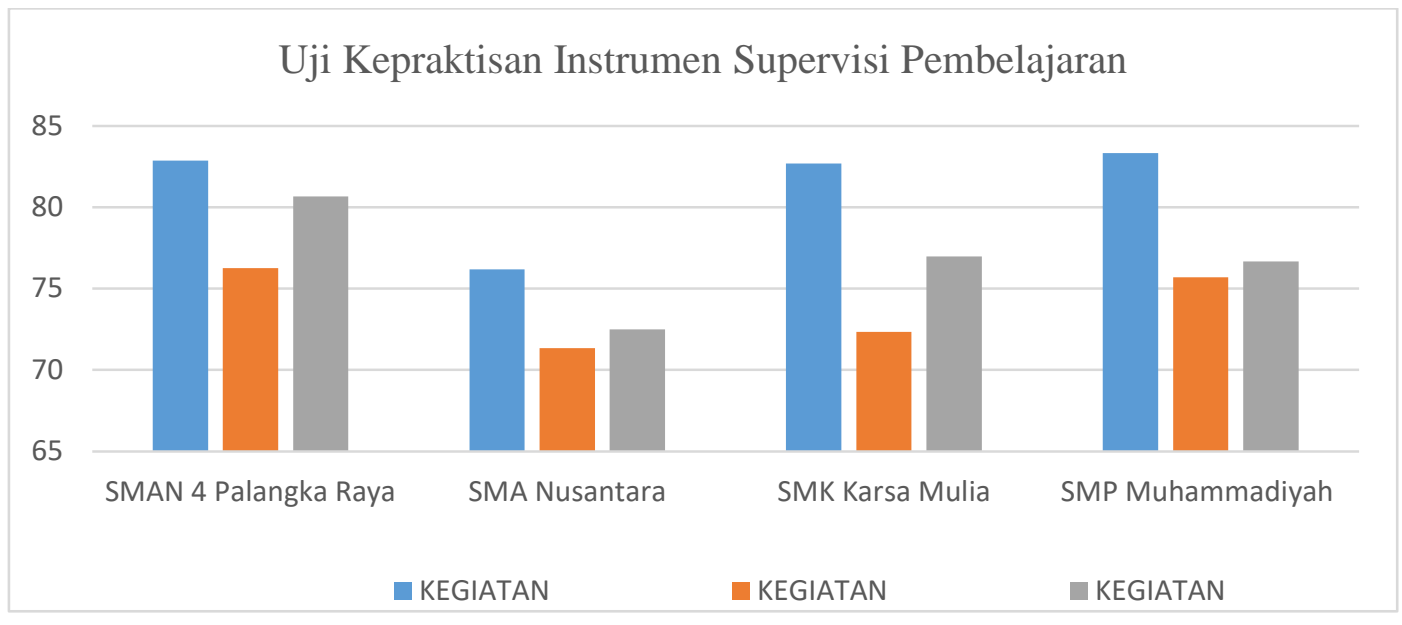

Gambar 3 Hasil Perolehan Skor Uji Kepraktisan Instrumen Supervisi

Keberhasilan melakukan telaah RPP guru-guru di sekolah binaan melalui bimbingan profesional dari pengawas menurut Dharma, S (2007:40) menyimpulkan bahwa pelaksanaan supervisi akademik diawali dengan tahapan (1) mengembangkan instrumen pengumpulan data/informasi dalam rangka identifikasi dan analisis masalah/kebutuhan pengembangan, (2) mengembangkan instrumen pengukuran keefektifan proses pelaksanaan supervisi akademik proses pembelajaran, pendekatan, dan teknik supervisi akademik yang diterapkan, (3) mengembangkan instrumen pengukuran pencapaian hasil (output) supervisi akademik selama pembelajaran, dan (4) mengembangkan instrumen pengukuran keefektifan pencapaian dampak (outcome) supervisi akademik setelah pembelajaran.

Adanya instrumen telaah RPP dan supervisi guru tidak serta merta menghilangkan kualitas pembelajaran di kelas. Efektivitas pembelajaran oleh guru harus memenuhi enam prinsip penelitian Elizabet Newton seperti yang dipaparkan Ruoding Shi (2007) menyimpulkan pembelajaran harus melibatkan enam akronim SUCCESs, yaitu simple, unecpected, concrete, credibility, emotional, dan stories. Pertama, guru mengajar harus simple yaitu guru harus mempersiapkan inti dari materi yang akan disampaikan. Kedua, unexpected selama pembelajaran ada sesuatu yang tidak diduga dapat dihadirkan oleh guru. Misalnya memberikan hadiah kepada yang berhasil menjawab pertanyaan. Menayangkan video yang relevan dengan KD. Ketiga, concrete yaitu menghadirkan sesuatu yang nyata di kelas dapat dilihat, disentuh, dan dirasakan oleh siswa. Keempat, credibility, guru harus dapat dipercaya, yaitu KD yang disampaikan penting dan bermanfaat bagi pengembangan potensi peserta didik. Kelima, emotional pembelajaran yang diberikan guru harus dapat memberikan sentuhan keterlibatan peserta didik secara emotional. Keenam, stories pembelajaran harus disertai dengan cerita karena membuat peserta didik untuk terhibur untuk selanjutnya menjadi lebih fokus.

\section{SIMPULAN DAN SARAN}

Berdasarkan data dan pembahasan dalam penelitian yang dilaksanakan dengan rancangan penelitian $\mathrm{R} \& \mathrm{D}$ dapat disimpulkan (1) model faktual instrumen supervisi akademik di sekolah binaan Provinsi Kalimantan Tengah maupun binaan SPMI Kota Palangka Raya belum (a) memenuhi aspek 
kepraktisan substansi dan deskripsi RPP, (b) digunakan sebagai acuan oleh guru dalam menyempurnakan RPP, dan (c) hanya digunakan oleh Pengawas Pembina; (2) Tahap pengembangan instrumen telaah RPP berbasis keterampilan abad 21 dan supervisi pembelajaran yaitu: (a) menentukan substansi deskripsi RPP dengan mempertimbangkan kepraktisan telaah RPP mulai dari identitas dan KD, perumusan tujuan mengacu IPK, proses pembelajaran memuat kegiatan pendahuluan, inti, dan penutup (penilaian) serta tiga aspek pada supervisi pembelajaran yaitu kegiatan pendahuluan (orientasi, motivasi, dan apersepsi), kegiatan inti (pemilihan model pembelajaran, pemanfaatan sumber belajar/media pembelajaran), serta kegiatan penutup (proses refleksi dan pelaksanaan penilaian dan hasil belajar), (b) validasi instrumen menurut ahli menyimpulkan instrumen telah sesuai dari aspek sahih (akurasi), tingkat kepentingan, dan kebermanfaatan dengan rata-rata prosentase mencapai 92,19, (c) menyusun instrumen telaah RPP dan supervisi pembelajaran dalam dua versi yaitu manual dan berbasis aplikasi excel, dan (3) tahap evaluasi yaitu uji coba kepraktisan instrumen menunjukkan bahwa (a) memudahkan observer dalam melakukan telaah RPP dan supervisi pembelajaran, (b) membantu guru dalam menyempurnakan RPP sesuai dengan kelengkapan komponen yang harus ada dalam RPP, (c) sekolah memiliki alat ukur telaah RPP dan supervisi pembelajaran, dan (d) instrumen berbasis excel yang berhasil dikembangkan sesuai dengan tuntutan keterampilan guru abad 21 dan revolusi industri 4.0. Saran yang dapat diajukan dalam penelitian ini adalah (1) sebaiknya pengawas sekolah mengembangkan instrumen dengan tahapan review instrumen yang lama, membuat draft instrumen, melakukan validasi draf instrumen, membuat instrumen mengacu hasil validasi, memperoleh instrumen baru, dan dilanjutkan dengan ujicoba terbatas, ditelaah untuk ujicoba lebih luas, (2) hendaknya pengawas sekolah selalu menggunakan instrumen dengan akurasi yang dapat dipercaya untuk memperoleh data yang akurat dan menggambarkan kondisi pembelajaran yang sebenarnya di masing-masing sekolah binaan, (3) hendaknya dalam mengembangkan instrumen pengawas sekolah memperhatikan faktor kesahihan (kebenaran), tingkat kepentingan, dan kebermanfaatan dengan menjabarkan indikator masing-masing aspek, dan (4) sebaiknya pengawas sekolah memberikan pendampingan kepada Kepala Sekolah dan Guru-guru agar supervisi pembelajaran diawali dengan (a) melakukan telaah RPP berbasis keterampilan abad 21, revisi RPP berdasarkan saran perbaikan secara komprehensif mulai dari kelengkapan komponen, kesesuaian IPK dengan KD, memuat materi faktual, konseptual, prosedural, dan metakognitif, menggunakan model pembelajaran yang sesuai dengan karakteristik $\mathrm{KD}$, merancang skenario pembelajaran, dan merancang hasil penilaian, serta memastikan implementasi keterampilan abad 21 pada RPP, kemudian melakukan kesepakatan dengan guru untuk pelaksanan supervisi kunjungan kelas.

\section{DAFTAR PUSTAKA}

Bakrun. 2018. Pelatihan dan Pendampingan Implementasi Kurikulum 2013 Sekolah Menengah Kejuruan, Materi Praktik Pembelajaran. Jakarta: Direktorat Pembinaan SMK.

BSNP. 2019. Sosialisasi Kebijakan Ujian Nasional Tahun 2019. File Paparan.

Dharma, S. 2014. Supervisi Akademik Implementasi Kurikulum 2013 untuk Kepala Sekolah. Jakarta: BPSDM 
Kemendikbud. 2018. Modul Supervisi Akademik Pendidikan dan Fungsional Calon Pengawas Sekolah dan Penguatan Kompetensi Pengawas Sekolah . Jakarta: Dirjen GTK Direktorat Pembinaan Tenaga Kependidikan.

Mulyadi (2018) tentang Pendekatan Supervisi Pengajaran Kolaboratif untuk Meningkatkan Kemampuan Guru Menyusun Rencana Pelaksanaan Pembelajaran Inovatif Bermuatan Nilai Karakter di SMK Binaan Kota Palangka Raya Semester 1 Tahun Pelajaran 2018/2019.

Peraturan Presiden Nomor 87 Tahun 2017 tentang Penguatan Pendidikan Karakter (PPK).

Ruoding Shi. 2007. Made to stick: Why some ideas survive and others die. Random House. http://www.engineerguy.com/whitepapers/ pdf/made-tostick.pdf. Diakses Pada 15 Agustu 2015, Pukul 19.30 WIB.

Sugiyono. 2013. Metode Penelitian Kuantitatif Kualitatif R\&D. Bandung: Alfabeta.

Surapranata, S .2017. M O1 SMA Modul Supervisi Akademik Kelompok Kompetensi A Program Pengembangan Keprofesian Berkelanjutan Pengawas Sekolah 2017. Jakarta: Direktorat PTK Dikdasmen

Winarni, E.W. 2018. Teori dan Praktik Penelitian Kuantitatif Kualitatif Penelitian Tindakan Kelas (PTK) Research and Development $(R \& D)$. Jakarta: Bumi Aksara. 


\section{Lampiran 1 Instrumen Telaah RPP Berbasis Keterampilan Abad 21 Kurikulum 2013}

\section{Nama Guru \\ Pangkat/Golongan \\ Jabatan \\ Unit Kerja}

Petunjuk:

Berikan nilai pada setiap komponen Rencana Pelaksanaan Pembelajaran (RPP) dengan cara membubuhkan tanda cek $(\sqrt{ })$ pada kolom hasil pengamatan skor $=0$ (tidak ada/tidak sesuai), skor 1 (kurang lengkap), skor 2 (sudah lengkap) sesuai dengan penilaian selama melakukan validasi telaah RPP. Berikan catatan perbaikan pada kolom revisi.

\begin{tabular}{|c|c|c|c|c|c|c|}
\hline \multirow{2}{*}{$\begin{array}{l}\mathrm{N} \\
\mathrm{O}\end{array}$} & \multirow{2}{*}{\multicolumn{2}{|c|}{$\begin{array}{c}\text { Komponen Rencana } \\
\text { Pelaksanaan Pembelajaran }\end{array}$}} & \multicolumn{3}{|c|}{$\begin{array}{l}\text { HASIL VALIDASI } \\
\text { KESESUAIAN }\end{array}$} & \multirow{2}{*}{$\begin{array}{l}\text { Catatan } \\
\text { revisi }\end{array}$} \\
\hline & & & 0 & 1 & 2 & \\
\hline \multirow[t]{2}{*}{ A } & & Identitas Mata Pelajaran & $\begin{array}{l}\text { Tdk.Ada } \\
\text { / Tidak } \\
\text { Sesuai }\end{array}$ & $\begin{array}{l}\text { Kurang } \\
\text { Lengkap/ } \\
\text { Kurang } \\
\text { Sesuai }\end{array}$ & $\begin{array}{l}\text { Sudah } \\
\text { Lengkap/ } \\
\text { Sudah } \\
\text { Sesuai }\end{array}$ & \\
\hline & 1 & $\begin{array}{l}\text { Terdapat: satuan } \\
\text { pendidikan, kelas, } \\
\text { semester, tahun pelajaran, } \\
\text { mata pelajaran, kompetensi } \\
\text { dasar, dan jumlah } \\
\text { pertemuan }\end{array}$ & & & & \\
\hline B. & \multicolumn{2}{|c|}{$\begin{array}{l}\text { Perumusan Tujuan } \\
\text { Pembelajaran sesuai IPK }\end{array}$} & $\begin{array}{l}\text { Tidak } \\
\text { Sesuai }\end{array}$ & $\begin{array}{l}\text { Sesuai } \\
\text { Sebagian }\end{array}$ & $\begin{array}{c}\text { Sesuai } \\
\text { Seluruhny } \\
\text { a }\end{array}$ & \\
\hline & 2 & $\begin{array}{l}\text { Menggambarkan lingkup } \\
\text { materi dalam KD } \\
\text { pengetahuan dan KD } \\
\text { keterampilan }\end{array}$ & & & & \\
\hline & 3 & $\begin{array}{l}\text { Rumusan tujuan } \\
\text { pembelajaran mengandung } \\
\text { komponen Audience, } \\
\text { Behaviour, Condition, dan } \\
\text { Degree }\end{array}$ & & & & \\
\hline & 4 & $\begin{array}{l}\text { Mengintegrasikan nilai- } \\
\text { nilai penguatan pendidikan } \\
\text { karakter (PPK) dalam } \\
\text { sikap, dan kecakapan abad } \\
21 \text { (literasi, } \\
\text { HOTS/penalaran, 4 C) } \\
\end{array}$ & & & & \\
\hline C. & \multicolumn{2}{|c|}{$\begin{array}{l}\text { Pemilihan Media/Model/Metode } \\
\text { pembelajaran }\end{array}$} & $\begin{array}{l}\text { Tidak } \\
\text { Sesuai }\end{array}$ & $\begin{array}{l}\text { Sesuai } \\
\text { Sebagian }\end{array}$ & $\begin{array}{c}\text { Sesuai } \\
\text { Seluruhnya }\end{array}$ & \\
\hline
\end{tabular}




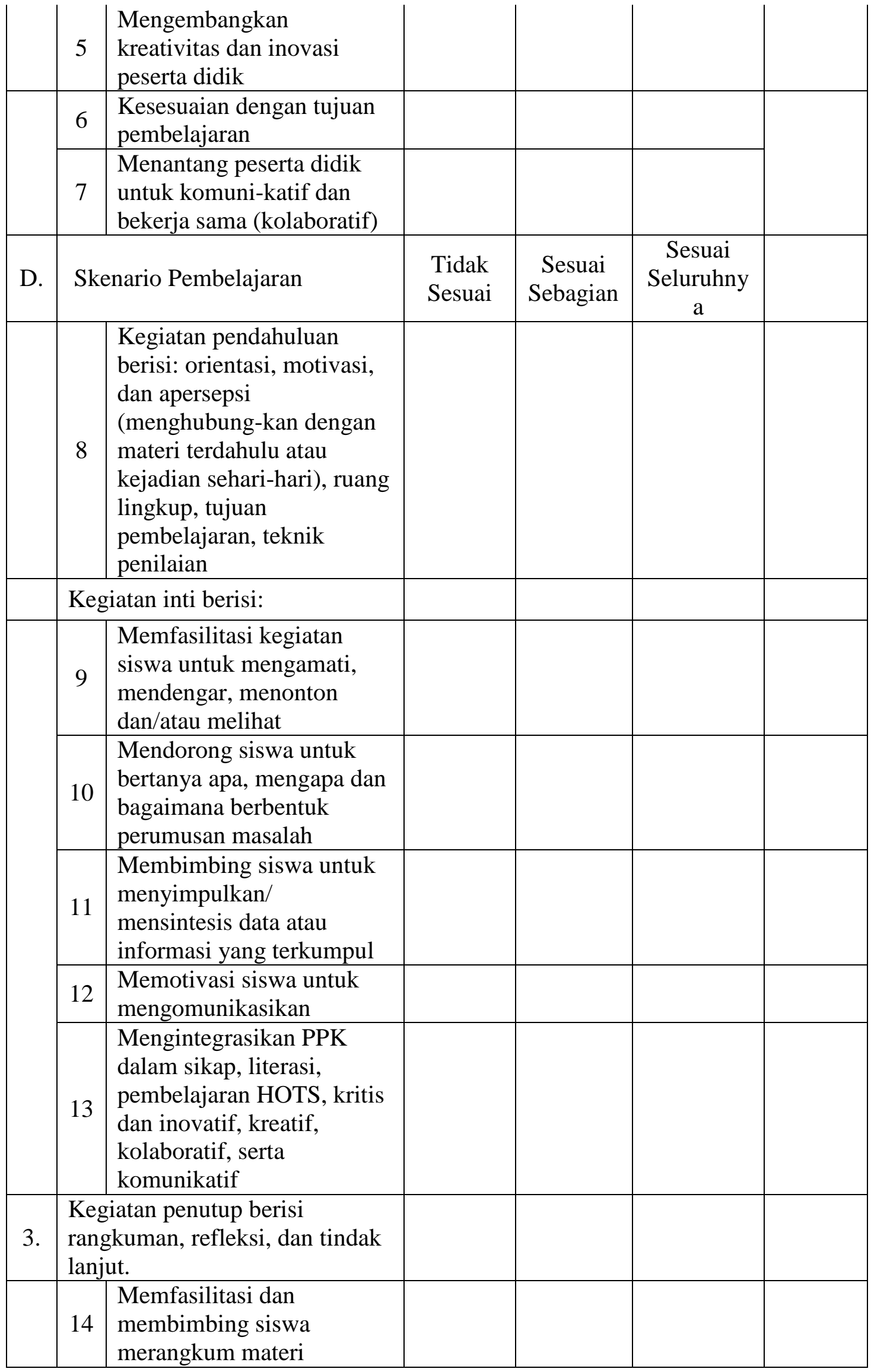




\begin{tabular}{|c|c|c|c|c|c|c|}
\hline & & pelajaran & & & & \\
\hline & 15 & $\begin{array}{l}\text { Memfasilitasi dan } \\
\text { membimbing siswa } \\
\text { merefleksi kegiatan yang } \\
\text { sudah dilaksanakan }\end{array}$ & & & & \\
\hline & 16 & $\begin{array}{l}\text { Memberikan umpan balik } \\
\text { terhadap hasil } \\
\text { pembelajaran }\end{array}$ & & & & \\
\hline E. & $\begin{array}{l}\text { Rar } \\
\text { Pen }\end{array}$ & $\begin{array}{l}\text { cangan Penilaian } \\
\text { belajaran }\end{array}$ & $\begin{array}{l}\text { Tidak } \\
\text { Sesuai }\end{array}$ & $\begin{array}{l}\text { Sesuai } \\
\text { Sebagian }\end{array}$ & $\begin{array}{l}\text { Sesuai } \\
\text { Seluruhny } \\
\text { a }\end{array}$ & \\
\hline & 17 & $\begin{array}{l}\text { Kesesuaian bentuk, teknik } \\
\text { dan instrumen dengan } \\
\text { indikator pencapaian } \\
\text { kompetensi }\end{array}$ & & & & \\
\hline & 18 & $\begin{array}{l}\text { Kesesuaian antara bentuk, } \\
\text { teknik dan instrumen } \\
\text { Penilaian Sikap }\end{array}$ & & & & $\begin{array}{l}\text { mapel } \\
\text { PPKn } \\
\text { dan } \\
\text { PABP }\end{array}$ \\
\hline & 19 & $\begin{array}{l}\text { Kesesuaian antara IPK } \\
\text { dengan instru-men } \\
\text { penilaian pengetahuan } \\
\text { menggam-barkan soal } \\
\text { HOTS (KD menganalisis, } \\
\text { mengevaluasi, dan } \\
\text { mencipta) }\end{array}$ & & & & \\
\hline & 20 & $\begin{array}{l}\text { Kesesuaian antara IPK } \\
\text { dengan instrumen Penilaian } \\
\text { Keterampilan berbasis soal } \\
\text { HOTS. }\end{array}$ & & & & \\
\hline & & Jumlah Skor & & & & \\
\hline & & Nilai dan Predikat & & & & $\begin{array}{c}\text { Skor } \\
40\end{array}$ \\
\hline
\end{tabular}


Nilai dihitung dengan rumus $=\frac{\text { Skor Perolehan }}{\text { Skor Maksimum }} \mathrm{x}$ 100

\begin{tabular}{|c|c|l|}
\hline Nomor & Skor & \multicolumn{1}{|c|}{ Predikat } \\
\hline 1. & $90-100$ & A (Amat Baik) \\
\hline 2. & $80-89$ & B (Baik) \\
\hline 3. & $65-79$ & C (Cukup) \\
\hline 4. & $55-64$ & D (Kurang) \\
\hline 5. & $0-54$ & E (Sangat Kurang) \\
\hline
\end{tabular}

Hasil Observasi dan Kesimpulan.

1. Saran secara umum perbaikan terhadap RPP yang ditelaah

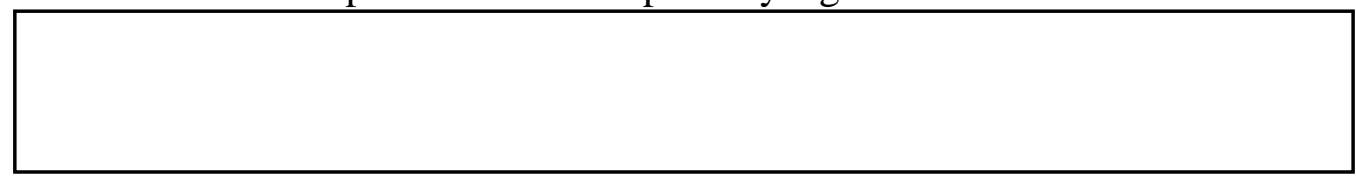

2. Kesesuian RPP aspek subtansi KD, Kepraktisan, dan Standar Proses

3. RPP telah memuat kecapakan abad 21 mulai dari PPK, literasi, Pembelajaran HOTS, dan 4C

4. Kesimpulan terhadap RPP

Observer,

NIP.
Guru yang diobservasi,

Mengetahui:

NIP.

Kepala Sekolah,

NIP. 


\section{Lampiran 2 Instrumen Supervisi Pembelajaran Berbasis Keterampilan Abad 21}

$\begin{array}{lc}\text { Nama Sekolah } & : \\ \text { Nama Guru } & : \\ \text { Mata pelajaran } & : \\ \text { Kelas/Semester } & : \\ \text { Kompetensi Dasar } & :\end{array}$

Petunjuk:

Berikan nilai pada setiap aspek yang diamati pada Pelaksanaan Pembelajaran dengan cara membubuhkan tanda cek $(\sqrt{ })$ pada kolom hasil pengamatan dengan memberikan skor $=0$ (yang dilakukan guru/siswa tidak sesuai), skor 1 (yang dilakukan guru/siswa sesuai sebagian), skor 2 (yang dilakukan guru/siswa sangat sesuai) selama Anda mengamati guru yang diobservasi.

\begin{tabular}{|c|c|c|c|c|c|}
\hline \multirow{3}{*}{ No } & \multirow{3}{*}{$\begin{array}{c}\text { Aspek yang Diamati: Pelaksanaan } \\
\text { Pembelajaran }\end{array}$} & \multicolumn{3}{|c|}{$\begin{array}{l}\text { Hasil Pengamatan } \\
\text { dan Skor }\end{array}$} & \multirow[t]{3}{*}{$\begin{array}{l}\text { Catatan/ } \\
\text { Deskripsi }\end{array}$} \\
\hline & & 0 & 1 & 2 & \\
\hline & & $\begin{array}{l}\text { Tidak } \\
\text { sesuai }\end{array}$ & $\begin{array}{c}\text { Sesuai } \\
\text { sebagian }\end{array}$ & $\begin{array}{l}\text { Sangat } \\
\text { sesuai }\end{array}$ & \\
\hline \multirow[t]{2}{*}{ A. } & Kegiatan Pendahuluan & & & & \\
\hline & Orientasi & & & & \\
\hline \multirow[t]{2}{*}{1} & $\begin{array}{l}\text { - Menyampaikan tujuan, rencana } \\
\text { kegiatan baik, individual, kerja } \\
\text { kelompok, dan melakukan } \\
\text { observasi. }\end{array}$ & & & & \\
\hline & Motivasi & & & & \\
\hline 2 & $\begin{array}{l}\text { - Mengajukan pertanyaan yang } \\
\text { menantang terkait dengan KD yang } \\
\text { akan dipelajari untuk memotivasi. }\end{array}$ & & & & \\
\hline \multirow[t]{2}{*}{3} & $\begin{array}{l}\text { Menyampaikan manfaat materi } \\
\text { terkait KD pembelajaran dengan } \\
\text { kehidupan sehari-hari. }\end{array}$ & & & & \\
\hline & Apersepsi & & & & \\
\hline 4 & $\begin{array}{l}\text { Menganalisis keterkaitan KD } \\
\text { sebelumnya dengan materi baru } \\
\text { sekaligus strategi pembelajaran } \\
\text { yang akan digunakan. }\end{array}$ & & & & \\
\hline 5 & $\begin{array}{l}\text { Nilai karakter yang muncul: } \\
\text { - Keterampilan abad } 21\end{array}$ & & & & $\begin{array}{l}\text { - Literasi } \\
\text { - Karakter }\end{array}$ \\
\hline B. & Kegiatan Inti & & & & \\
\hline 6. & $\begin{array}{l}\text { *) Pada kegiatan inti ini gunakan } \\
\text { sintak setiap model sesuai } \\
\text { instrumen yang ada }\end{array}$ & & & & $\begin{array}{l}* \text { ) } \\
\text { Minimal } 5 \\
\text { langkah } \\
\text { (skor 10) }\end{array}$ \\
\hline & $\begin{array}{l}\text { Pemanfaatan sumber belajar/media } \\
\text { pembelajaran }\end{array}$ & & & & \\
\hline
\end{tabular}




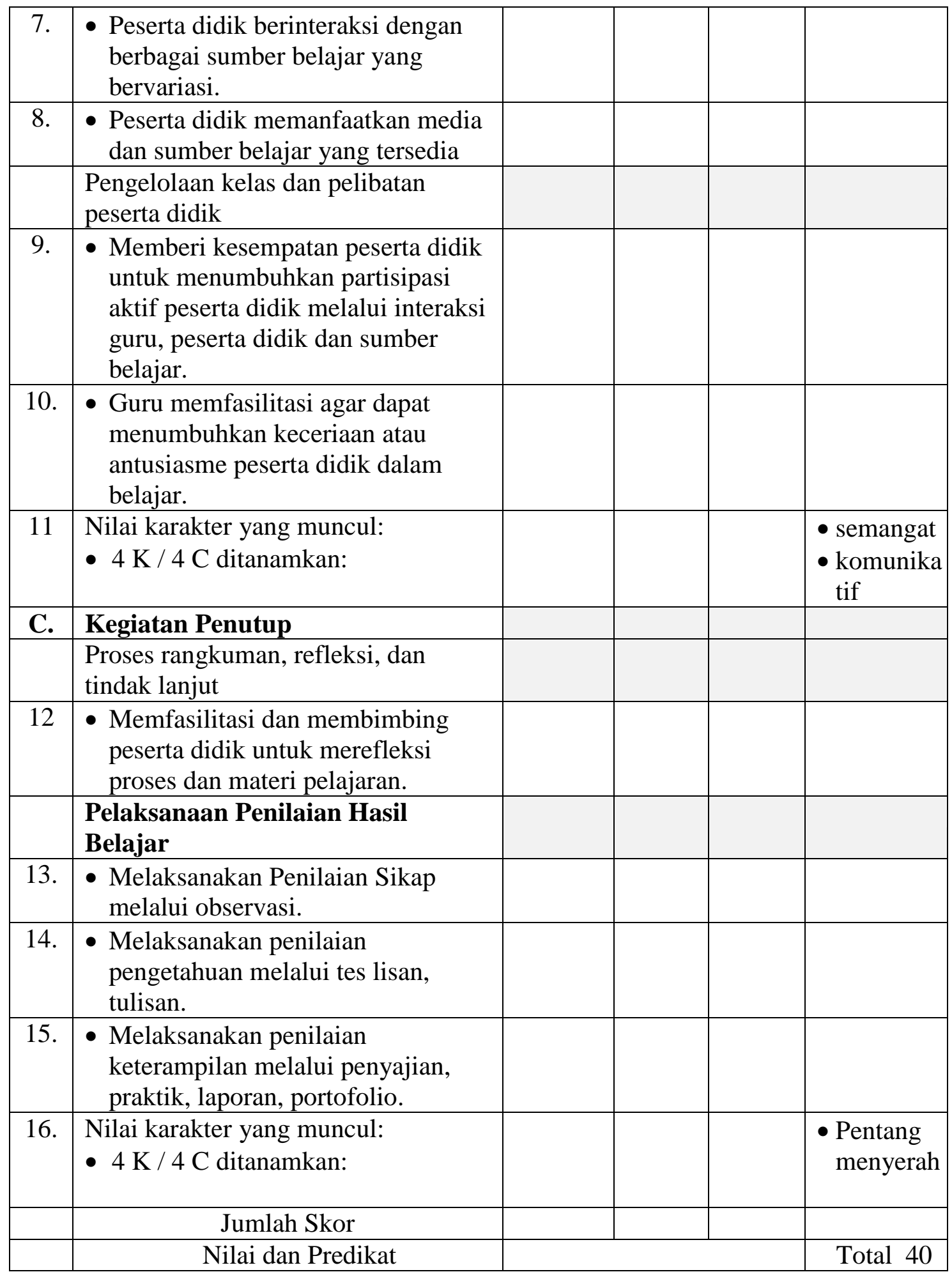

Nilai dihitung dengan rumus $=$ $\frac{\text { Skor Perolehan }}{\text { Skor Maksimum }} \times 100$

$=\ldots$.

\begin{tabular}{|c|l|l|}
\hline Nomor & \multicolumn{1}{|c|}{ Skor } & \multicolumn{1}{c|}{ Predikat } \\
\hline 1. & $90-100$ & A (Amat Baik) \\
\hline 2. & $80-89$ & B (Baik) \\
\hline 3. & $65-79$ & C (Cukup) \\
\hline 4. & $55-64$ & D (Kurang) \\
\hline 5. & $0-54$ & E (Sangat Kurang) \\
\hline
\end{tabular}


Hasil Observasi dan Kesimpulan.

1. Observer menanyakan kelebihan guru selama pembelajaran

Catatan observer selama pembelajaran

2. Hasil penilaian menurut observer diklarifikasi dengan guru yang diobservasi sehingga disepakati oleh kedua pihak.

3. Kesimpulan hasil supervisi, guru diberikan pembinaan tidak langsung (nilai perolehan $\geq 80$ ) guru diberikan pembinaan langsung (nilai perolehan $<80$ ).

NIP.

NIP.

Mengetahui:

Kepala Sekolah,

NIP. 